\title{
IMPLEMENTATION OF ECONOMIC ORDER QUANTITY (EOQ) ON INVENTORY EFFICIENCY IN PT. HEALTH TODAY INDONESIA
}

\author{
Al Adawiyah ${ }^{1}$ \\ Khoirul Umam ${ }^{2}$ \\ ${ }^{1}$ Alumni Indraprasta University PGRI \\ ${ }^{2}$ Lecturer at Indraprasta University PGRI Economic Education Study Program \\ Email: Khoirul.elmariachi@gmail.com
}

\begin{abstract}
Optimal inventory management is one of the main problems that is often encountered in the company's production activities which leads to the company's overall efficiency and profitability. PT. Health Today Indonesia is one of the companies experiencing this problem. Thus, this descriptive research with a quantitative approach aims to find solutions to these problems. Secondary data analysis from the 2013-2016 report uses the Economic Order Quantity (EOQ) calculation model from several divisions that are relevant to the 5 main products namely Fruit Smoothies, Bubble, Trisco, Honey and Sunfield. The results showed that the company was able to increase production efficiency, but this was not an actual condition due to externalities and the company's internal policy to delay the addition of purchases of raw materials and inventory, making the trend of inefficiency of the company's production decreased.
\end{abstract}

Keyword: Economic Order Quantity, Inventory Management, Production

\section{INTRODUCTION}

One of the most important aspects of a company's production activities is managing the supply of raw materials and merchandise. The availability and adequacy of merchandise greatly influences the stability of the company's production activities which results in production costs (Heizer \& Render, 2012). On the other hand, companies are always required to reduce their costs by reducing inventory of merchandise that has not needed or are still in the queue waiting to be produced. So that the problems faced by the company is managing the availability of merchandise that is optimal in order to maintain stability in a sustainable production activities (Darmawan, copywriting, and Yulianthini, 2015).

At least, there are two fundamental problems faced by companies in planning an optimal inventory of merchandise (Darmawan et al., 2015). First, if there is a shortage of merchandise inventory, it will have an impact on the ability of the company to not be able to meet the needs of consumers properly, then it will disrupt the smooth production process as a whole. In this condition the company is faced with two choices, trying to meet consumer 
demand with the consequence of having to pursue the existing target demand, and of course it will bring additional costs such as doing a partner to another company, or applying over time to employees with consequences will add costs. Second, if there is an excess inventory of merchandise, it will be faced with the issue of interest in purchasing merchandise that is due, the expiration period of the goods themselves, additional costs to be incurred by the company in maintaining merchandise inventory while waiting for the production process that should not there needs to be, including contributing to the low return on investment (Return on Investment) of these products to the company (Muchaendepi, Mbohwa, Hamandishe, \& Kanyepe, 2019).

Good inventory management, will provide benefits to the company, which: companies can anticipate the occurrence of inventory fluctuations in production activities; anticipating fluctuations in demand and providing stock of goods that will provide choices for customers; get a discount if buying merchandise in large quantities; hedging and anticipation of inflation and fluctuating price movements in the future. (Heizer \& Render, 2012).

PT. Health Today Indonesia, a company that was founded in 2007 in the Grand Wijaya Center area and has its own factory in the BSD (Bumi Serpong Damai) area, is one company that is also experiencing problems regarding the optimal management of merchandise inventory. As a company engaged in the field of food and beverage, as well as an official distributor of beverage products such as approval, toping, additional flavor and coffee imported from Australia, China, Japan, Malaysia, Spain (Catunambu coffee), and Thailand, not only face the problem of availability the goods themselves, but also fluctuations in raw material prices were partly purchased imported.
The company's business development efforts supported by the development of the culinary (food and beverage) in Indonesia, which until now quite rapidly. This resulted in the level of purchases of raw materials and merchandise companies that do almost every month (local purchase) and purchases of imports carried out 3-4 times a year. Some products that are produced directly include: Powder, Liquid (syrup), and Pure Fruit (fruit juice). For imported products such as Fruit Smoothies, Sunfield Concentrate, Trisco, Tropical Pearl Boba, and Bubble. Inventory of merchandise produced by the factory in the form of powder which is the most salable in the market, namely: green tea creme, taro creme, chocolate classic, dark chocolate, smoothies base, and vanilla. While the imported products purchased by this company are the most popular Fruit Smoothies in the market, black currants and strawberries. For imported products, PT. Health Today also presents a topping for beverages, the most sold in the market, namely: Trisco Chocolate. As well as additional flavors for tea lovers such as Honey Plum and Honey Citroen, an easy way to serve tea such as lemon flavor and sweetness of honey.

Procurement of raw material supplies is done by making purchase orders to suppliers for both domestic and imported purchases. The products sold are distributed to several hotels, retails, restaurants and bakery shops in several locations such as Surabaya, Bandung, Yogyakarta, Medan, Makassar and Bali. For sales agents in the DKI Jakarta and surrounding areas, purchases of goods from the warehouse are carried out by COD (Cash on Delivery).

Information obtained regarding the merchandise during the 4 years of the study are presented in Table 1 below. 
Table 1. Total inventory of merchandise from 2013-2016.

\begin{tabular}{lc}
\hline Years & $\begin{array}{c}\text { Merchandise Inventory } \\
(\text { Rp) }\end{array}$ \\
\hline 2013 & $3.129 .172 .176,08$ \\
2014 & $2.891 .637 .549,02$ \\
2015 & $2.842 .347 .564,07$ \\
2016 & $2.738 .112 .285,48$ \\
\hline
\end{tabular}

Within a period of four years (20132016), the problems faced included building an integrated warehouse management system, a short product expiry period, falling demand for several items resulting in some goods and raw materials being discontinuous, as well as the problem of product turnover and raw materials are still stored in the warehouse, causing the company's policy to postpone the purchase of goods and the addition of new raw materials for the sake of cost efficiency. Coupled with the licensing process that requires time to purchase goods and imported raw materials by the company.

The condition of the company is what makes researchers interested in exploring how inventory management is carried out by the company; what policies companies must take in managing their inventory; solutions that must be taken by the company in providing optimal inventory of goods in order to meet market demand in order to find solutions for good inventory management for the company to increase company productivity in the long run from the aspect of production activities.

The results of the study explained that the inventory for a company is a very important part in an effort to win business competition. Inventory can also anticipate fluctuations in consumer demand, this is particularly beneficial for the company's long-term business stability (Singh \& Verma, 2018). For the company itself, the management of resources, especially good inventory, can make the company more flexible and responsive in the face of uncertain business changes. Especially to reduce the risk of uncertainty and increase competitive advantage in the distribution of goods (Koh \& Simpson, 2007).
Discussing the uncertainty of demand and the time limit for ordering goods, Iqbal (Iqbal, Aprizal, \& Wali, 2017) explained that there were two main problems that would occur including: first, the desire of the company to build a reserve inventory that would incur new additional costs. Second, if the stock is not held, then run out of supplies will cost as compensation for the interruption of the system, productivity, and others.

One model that is often used by companies in managing and controlling the inventory of goods is the Economic Order Quantity. In applying this model, Heizer provides assumptions such as: 1) The large number of requests must be known with certainty, constant and not affected by other factors that result in changes in the number of requests; 2) Lead Time, which is the waiting time between order and receipt of order, must be known with certainty and consistency; 3) Inventories received must arrive promptly and completely; 4) It must be ensured that there are no discounts due to the reduction in the amount of inventory; 5) Existing Variable Cost consists only of ordering costs and storage costs of goods calculated from time to time; 6) timely order and receipt of goods will be able to overcome the problem of inventory vacancy (Heizer \& Render, 2012). The purpose of applying the inventory management model is to determine the optimal capacity of the inventory of goods ordered and the level of inventory of finished goods in order to maximize company profits (Cárdenas-Barrón, Shaikh, Tiwari, \& Treviño-Garza, 2020).

Reorder Points (ROP), is one of the components contained in the calculation of the EOQ model. ROP is a point level limit of the amount of inventory and at that point the company should re-ordering of goods inventories (Heizer \& Render, 2012). In practice, the decision ROP should be done precisely and quickly, both the time of booking and the amount of goods ordered. There are at least two problems arise if the 
company does not perform ROP. First, if the company is late in conducting an ROP, there will be a shortage of raw materials or stock out costs. Secondly, if the company starts ROP too early, there will be an extra carrying cost ((Siagian 2005) in Lukmana $\& Y, 2015)$.

While safety stock, is a reserve of inventory to protect the continuity of the production process in order to be protected from shortages of goods. The determination of the appropriate safety stock should use statistical analysis to take into account deviations occurring between inventory supply ideal with the real user (Dangnga, 2014). For companies, the safety stock is useful to protect the company from the risk of running out of raw materials (stock out), delays in the receipt of raw materials are ordered, the anticipated surge in demand which are not predictable in advance by the company (Darmawan et al., 2015).

\section{RESEARCH METHOD}

This research is a descriptive study with a quantitative approach. Subjects studied were PT Health Today Indonesia, which is engaged in food and beverage in the Grand Wijaya Center area. The type of data used in this study is 5 product data (Fruit Smoothies, Bubble, Trisco, Honey, Sunfield), order costs, storage costs, price per product unit, maximum inventory amount, reorder points for each product, safety stock and Economic data Order Quantity. Sources of data obtained from the report of the Purchasing division (as the party that orders goods), Accounting (the party that calculates the amount and percentage of costs incurred by the company), Warehouse (the party that regulates the flow of expenditure and receipt of goods and checking inventory of goods in the warehouse), and Marketing Communications (the party that coordinates the amount of merchandise inventory from consumer demand). Data analysis techniques from 2013 to 2016 used the Economic Order Quantity (EOQ) calculation model.

\section{RESULTS ANALYSIS}

In general, the Economic Order Quantity formula is as follows:

$$
\text { EOQ }=\sqrt{\frac{2 D S}{H}}
$$

Where:

D: Number of items needed 1 year

S: Costs every time you order

$\mathrm{H}$ : Storage cost per unit

While the formula for calculating $\mathrm{Re}$ Order Points is as follows:

ROP = Safety Stock + (Lead time x Q $)$

Where:

ROP : Re Order Point

Safety Stock : Reserve safety stock

Lead Time : Waiting time for unit delivery

Q

day

: The number of items per

Based on the formula above, the data and calculation results are presented in the table below. The results of the research obtained from the data show that the lead time in production activities is 6 days, assuming 1 year is 300 days. Table 2 shows the inventory data is optimal (EOQ), safety stock, reorder point, supplies a maximum of (real) has been carried out by the company in the period from 2013 to 2016 , with 5 items of products sold that is Fruit Smoothies, Bubble, Trisco, Honey, Sunfield.

Table 2. EOQ, Safety Stock, ROP \& Maximum Inventory

\begin{tabular}{llrrrr}
\hline & Item & \multicolumn{4}{c}{ YEARS } \\
\cline { 2 - 5 } (Unit) & $\mathbf{2 0 1 3}$ & $\mathbf{2 0 1 4}$ & $\mathbf{2 0 1 5}$ & $\mathbf{2 0 1 6}$ \\
\hline \multirow{6}{*}{ Fruit } & 5.992 & 4.032 & 5.385 & 4.598 \\
& Smoothies & & & & \\
& Bubble & 685 & 638 & 1.121 & 1.141 \\
EOQ & Trisco & 1.588 & 666 & 863 & 738 \\
& Honey & 100 & 713 & 1.707 & 2.033 \\
& Sunfield & 7.725 & 8.818 & 9.613 & 9.470 \\
& Total & 16.09 & 14.86 & 18.68 & 17.98 \\
& Fruit & 0 & 7 & 9 & 0 \\
Safet & Smoothies & 1.600 & 1.000 & 1.000 & 1.000 \\
y & Bubble & 120 & 120 & 120 & 120 \\
Stock & Trisco & 120 & 120 & 120 & 120 \\
& Honey & $0^{*)}$ & 180 & 180 & 180 \\
& & & & &
\end{tabular}




\begin{tabular}{|c|c|c|c|c|c|}
\hline \multirow{2}{*}{\multicolumn{2}{|c|}{$\begin{array}{l}\text { Item } \\
\text { (Unit) }\end{array}$}} & \multicolumn{4}{|c|}{ YEARS } \\
\hline & & 2013 & 2014 & 2015 & 2016 \\
\hline \multirow{8}{*}{$\begin{array}{l}\text { Re } \\
\text { Order } \\
\text { Point } \\
\text { (ROP } \\
\text { ) }\end{array}$} & Sunfield & 1.200 & 1.200 & 1.200 & 1.200 \\
\hline & Total & 3.040 & 2.620 & 2.620 & 2.620 \\
\hline & $\begin{array}{l}\text { Fruit } \\
\text { Smoothies }\end{array}$ & 1.900 & 1.192 & 1.210 & 1.180 \\
\hline & Bubble & 138 & 138 & 144 & 144 \\
\hline & Trisco & 150 & 138 & 138 & 132 \\
\hline & Honey & 2 & 192 & 210 & 216 \\
\hline & Sunfield & 1.422 & 1.470 & 1.398 & 1.380 \\
\hline & Total & 3.612 & 3.130 & 3.100 & 3.052 \\
\hline \multirow{8}{*}{$\begin{array}{l}\text { Maxi } \\
\text { mum } \\
\text { Inven } \\
\text { tory }\end{array}$} & Fruit & 14.91 & & 10.38 & \\
\hline & Smoothies & 0 & 9.586 & 4 & 8.960 \\
\hline & Bubble & 817 & 780 & 1.234 & 1.296 \\
\hline & Trisco & 1.596 & 794 & 948 & 692 \\
\hline & Honey & 90 & 558 & 1.424 & 1.728 \\
\hline & Sunfield & $\begin{array}{r}11.23 \\
2\end{array}$ & $\begin{array}{r}13.58 \\
4\end{array}$ & 9.983 & 8.943 \\
\hline & Total & 28.64 & 25.30 & 23.97 & 21.61 \\
\hline & Fotal & 5 & 2 & 3 & \\
\hline
\end{tabular}

Source: processed data
Lead time $=6$ days; 1 year $=300$ days

*) For Honey products, they have only entered 2013 and are currently on trial, so the ROP cannot be calculated this year

Based on the data presented in Table 2 , it appears that the total real production capacity (maximum inventory) owned by the company experienced a significant decline every year, while the total EOQ experienced considerable fluctuations. On the other hand, although the total Re Order Points and safety stock have decreased, the trend tends not to fluctuate.

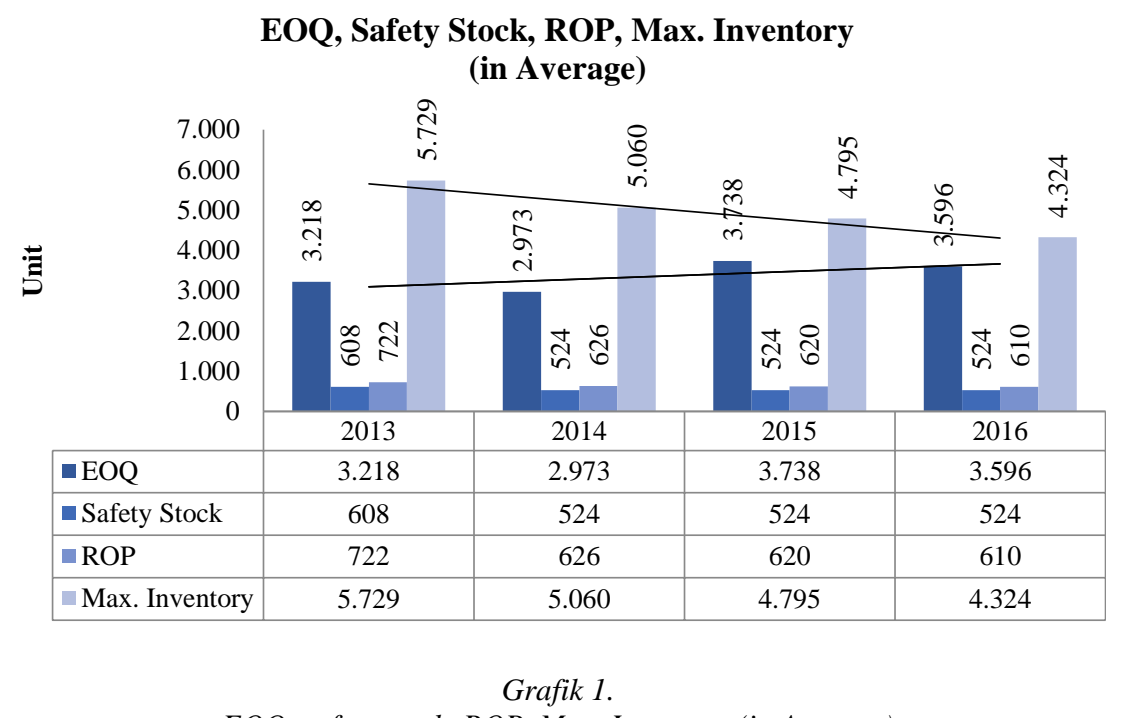

$E O Q$, safety stock, ROP, Max. Inventory (in Average)

Graph 1 presents data on average total production of 5 items (Fruit Smoothies, Bubble, Trisco, Honey, Sunfield) each year for each component of the EOQ calculation. It can be seen that the trend of EOQ in a linear fashion over the past 4 years has increased, while the trend of maximum capacity has decreased linearly.

Table 3 Unit Price, Order Fee, Storage Fee

\begin{tabular}{|c|c|c|c|c|c|}
\hline \multirow{2}{*}{$\begin{array}{l}\text { Iten } \\
\text { (Rp }\end{array}$} & & \multicolumn{4}{|c|}{ Years } \\
\hline & & 2013 & 2014 & 2015 & 2016 \\
\hline \multirow{6}{*}{ Price per Unit } & $\begin{array}{l}\text { Fruit } \\
\text { Smoothies }\end{array}$ & 148.611 & 170.873 & 172.413 & 193.066 \\
\hline & Bubble & 95.043 & 95.000 & 96.653 & 100.000 \\
\hline & Trisco & 77.363 & 126.682 & 112.700 & 113.923 \\
\hline & Honey & 52.920 & 62.177 & 70.720 & 81.767 \\
\hline & Sunfield & 72.704 & 89.785 & 78.856 & 72.122 \\
\hline & Average & 89.328 & 108.903 & 106.268 & 112.176 \\
\hline Orderg Costs & Fruit & 35.782 .000 & 2.875 .800 & 48.155 .150 & 45.551 .500 \\
\hline
\end{tabular}




\begin{tabular}{|c|c|c|c|c|c|}
\hline \multirow{2}{*}{$\begin{array}{l}\text { Item } \\
(\mathbf{R p})\end{array}$} & & \multicolumn{4}{|c|}{ Years } \\
\hline & & 2013 & 2014 & 2015 & 2016 \\
\hline \multirow{12}{*}{$\begin{array}{c}\text { Storage Costs } \\
\text { (20\% to price per unit) }\end{array}$} & Smoothies & & & & \\
\hline & Bubble & 5.459 .500 & 4.954 .700 & 9.839 .800 & 10.046 .900 \\
\hline & Trisco & 12.230 .000 & 7.084 .400 & 8.845 .800 & 8.957 .300 \\
\hline & Honey & 585.700 & 5.673 .400 & 14.478 .700 & 19.549 .700 \\
\hline & Sunfield & 38.629 .160 & 51.397 .575 & 73.002 .000 & 72.318 .500 \\
\hline & Average & 18.537.272 & 14.397 .175 & 30.864 .290 & 31.284 .780 \\
\hline & $\begin{array}{l}\text { Fruit } \\
\text { Smoothies }\end{array}$ & $29.722,2$ & $34.174,6$ & $34.482,6$ & $38.613,2$ \\
\hline & Bubble & $19.008,6$ & $19.000,0$ & $19.330,6$ & $20.000,0$ \\
\hline & Trisco & $15.472,6$ & $25.336,4$ & $22.540,0$ & $22.784,6$ \\
\hline & Honey & $10.584,0$ & $12.435,4$ & $14.144,0$ & $16.353,4$ \\
\hline & Sunfield & $14.540,8$ & $17.957,0$ & $15.771,2$ & $14.424,4$ \\
\hline & Average & 17.866 & 21.781 & 21.254 & 22.435 \\
\hline
\end{tabular}

Table 3, shows the amount of Unit Prices, Order Costs and Storage Costs expressed in rupiah and calculated in an average amount. Referring to the table, it appears that the movement of the unit price, booking fees and storage costs over a period of 4 years, an increase in a linear trend.

\section{INTERPRETATION}

The results showed that in the period of 4 years from 2013 to 2016, PT Health Today Indonesia was able to significantly reduce cost inefficiencies. Cost inefficiency is measured based on the difference from the company's maximum capacity to the optimal inventory that should be provided. In 2013 and 2014, there was a large difference in costs to the company's inventory capacity. This will certainly significantly reduce the company's profit. In Graph 2 it is presented that in 2013, the company's efficiency capability was only $56.2 \%$ or cost inefficiencies amounted to $\mathrm{Rp} 224,303,110$. In 2014, efficiency improvements occurred by $58.8 \%$ or cost inefficiencies amounted to $\operatorname{Rp} 227,281,396$. This means that the cost inefficiency that occurred in the two years is quite large when compared to the two years after that, namely in 2015 and 2016. In 2015, the company was able to increase its production efficiency by $78 \%$ or reduce the difference in costs by Rp 112,304,445, and in 2016 the company was again able to improve its efficiency better by $83.2 \%$ or by $\mathrm{Rp} 81,641,402$. This is presented in Graph 2 below

\section{Trend of Efficiency \& Inefficiency}

- Cost Inefficiency (Rp) Efficiency (\%)

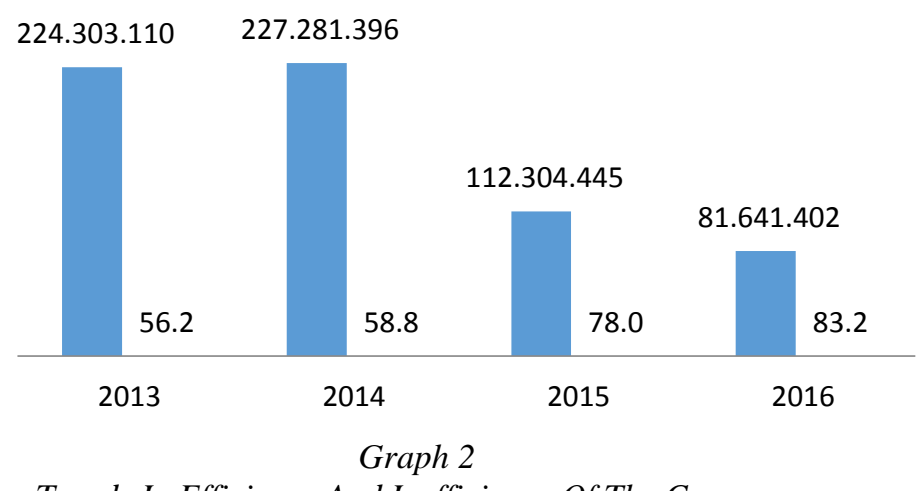

Trends In Efficiency And Inefficiency Of The Company 
However, the increase in cost efficiency was due to several conditions experienced by the company such as the improvement of the integrated goods and raw material management network system so that adjustments were made to recalculate and re-predict from previous conventional production targets. The period of expiry of raw materials and inventory so that the priority of the company's production policy is to prioritize the use of raw materials and inventory which are still available in warehouses rather than new purchases. The discontinuous factor of some merchandise items due to a decrease in consumer tastes also contributes to inventory management, thereby affecting the ordering of raw materials and the supply of these goods. It can be said that the efficiency of inventory management carried out by the company within a period of 4 years does not solely come from internal production and sales performance. External factors also contribute to managing the inventory of goods and raw materials.

If the condition lasts in the long run, it will disrupt the stability and sustainability of the company's overall production. In the end the company become uncompetitive and face great risk in overall productivity performance. In fact, if the increase in performance efficiency of the data is the real performance of the production and sales company which is running, you can bet the company will be able to reduce the risk of uncertainty, especially in the distribution of goods to meet consumer needs. In other words, the optimal management of inventory of goods and raw materials must refer to the performance of real production and sales up to date.

\section{CONCLUSION}

This research concludes several things that:

1. In the perspective of EOQ implementation in general, PT. Health Today Indonesia has been able to significantly improve efficiency in the period of 2013 to 2016 which is seen as a decrease in the gap between the optimal inventory and the maximum inventory capacity owned by the company as a real performance

2. External factors in the company's production activities contribute more so that it has an impact on reducing the maximum capacity of the company's goods inventory, in addition to the improvement of the internal system in managing inventory in the company

3. Characteristics of raw materials and goods produced by the company also contribute to the management of the company's inventory.

\section{IMPLICATIONS}

Some implication that can be given to companies are as follows:

1. PT. Health Today Indonesia must make improvements in the management of inventory of goods and raw materials with the event to make adjustments to the latest conditions of business development

2. The optimal inventory management of goods and raw materials of the company must be in line with the real productivity carried out by PT. Health Today Indonesia in order to increase the company's competitive ability in its business. That is, companies need to increase sales and demand for their products.

\section{REFERENCES}

Cárdenas-Barrón, L. E., Shaikh, A. A., Tiwari, S., \& Treviño-Garza, G. (2020). An EOQ inventory model with nonlinear stock dependent holding cost, nonlinear stock dependent demand and trade credit. Computers and Industrial Engineering, 139, 105557.

https://doi.org/10.1016/j.cie.2018.12.0 04 
Dangnga, M. T. (2014). ANALISIS PENERAPAN METODE ECONOMIC ORDER QUANTITY DAN REORDER POINT UNTUK PENGENDALIAN PERSEDIAAN BAHAN BAKU PADA P.T. JAPFA COMFEED INDONESIA TBK DI KOTA MAKASSAR. Economix, 2(2).

Darmawan, G. A., Cipta, W., \& Yulianthini, N. N. (2015). PENERAPAN ECONOMIC ORDER QUANTITY (EOQ) DALAM PENGELOLAAN PERSEDIAAN BAHAN BAKU TEPUNG PADA USAHA PIA ARIAWAN DI DESA BANYUNING TAHUN 2013 | . | Jurnal Manajemen Indonesia. Jurnal Manajemen Indonesia, 3(1). Retrieved from

https://ejournal.undiksha.ac.id/index.p $\mathrm{hp} / \mathrm{JMI} /$ article/view/4585

Heizer, J., \& Render, B. (2012). Operations Management: Flexible Version. (S. Yagan, Ed.) (10th ed.). New Jersey, USA: Prentice Hall.

Iqbal, T., Aprizal, D., \& Wali, M. (2017). Aplikasi Manajemen Persediaan Barang Berbasis Economic Order Quantity (EOQ). Jurnal JTIK (Jurnal Teknologi Informasi Dan Komunikasi), $\quad$ 1(1), 48. https://doi.org/10.35870/jtik.v1i1.33

Koh, S. C. L., \& Simpson, M. (2007). Could enterprise resource planning create a competitive advantage for small businesses? Benchmarking, 14(1), 59-76. https://doi.org/10.1108/146357707107 30937

Lukmana, T., \& Y, D. T. (2015). Penerapan Metode EOQ dan ROP (Studi Kasus: PD. BARU). Jurnal Teknik Informatika Dan Sistem Informasi, 1(3), 271-279. https://doi.org/10.28932/JUTISI.V1I3. 597

Muchaendepi, W., Mbohwa, C., Hamandishe, T., \& Kanyepe, J. (2019). Inventory management and performance of SMEs in the manufacturing sector of Harare. Procedia Manufacturing, 33, 454461.

https://doi.org/10.1016/j.promfg.2019. 04.056

Singh, D., \& Verma, A. (2018). Inventory Management in Supply Chain. In Materials Today: Proceedings (Vol. 5, pp. 3867-3872). Elsevier Ltd. https://doi.org/10.1016/j.matpr.2017.1 1.641 